\title{
THE EFFECT OF COOPERATIVE LEARNING MODEL UPON READING COMPREHENSION OF ELEVEN GRADE STUDENTS OF SMA NEGERI 1 SELONG DIFFERING IN READING INTEREST LANGUAGE EDUCATION
}

\author{
Pahrurrozi, AAIN Marhaeni, Nyoman Dantes \\ Language Education Study Program Postgraduate Program Ganesha University Of Education Singaraja \\ e-mail: Pahrurrozi@pasca.undiksha.ac.id
}

\begin{abstract}
This study aimed at finding out The Effect Of Cooperative Learning Model Upon Reading Comprehension Of Eleven Grade Students Of SMA NEGERI 1 SELONG Differing In Reading Interest. This study was experiment research used post-test only control group design. This study used random sampling technique involved 84 students consisted of eight classes that had the same competence. And then all classes were given random classes to determine the experimental group and the control group. consisted of 42 students. After that groups were given the reading interest questionnaire. From the analysis of the questionnaire , $33 \%$ (21 students ) of the high reading interest and $33 \%$ (21 students) of the low reading interest were determined from of each group as samples. Data were collected using reading test and questionnaire reading interest. The data were analyzing two- way ANOVA. The data of the students' achievement were obtained reading comprehension. Reading comprehension data were collected through a questionnaire of reading interest. Both of reading comprehension and reading interest had been validated before being applied to the research sample. Next, the data that were obtained were analyzed by using Two-way ANAVA analysis and Tukey Test. The result of this research is as follows: (1) There was a significant difference between the achievement of the students who were taught by cooperative learning model and those who were taught by using conventional learning model . (2) There was an interaction between the usage of cooperative learning model and reading comprehension upon students' reading interest. From the result of this research, it can be concluded that the learning model had significant effect towards the students reading comprehension. The difference of reading comprehension mentioned shows that cooperative learning model is better or effective than conventional learning model. (3)There was a significant difference between the achievement of the students who had high reading interest being taught using cooperative learning model and those who were taught being conventional learning model. (4) there was a significant difference between the achievement of the students who had low reading interest being taught using cooperative learning model and those who were being taught using conventional learning model.
\end{abstract}

Key Words: Cooperative Learning Model, Conventional Learning Model, Reading comprehension and students' reading interest

\section{INTRODUCTION}

Language is important part of human's life all over the world. In reality, language is a means of conveying ideas, mind, opinion and feeling. Language is also called as a social semiotic system (Haliday, 1973:125). This means that language is used by society as means of social interaction; English is an international language used by people all over the world as means of communication. Considering that English has an important role of global era, so it is important to be taught since early ages in school (Depdiknas, 2006:183). Senior high school is one of the formal educations 
which include English as curriculum's content. It should be realized that English is one of foreign languages which is compulsorily taught from junior high school to university level in Indonesia.

Teaching English is considered very important to spread and to develop science technology and education. In this global era Indonesia increases intensities of using English as a means of communication in formal and informal situation. Thus, many experts regard that teaching English is started to be taught from elementary level to university. In senior high school, English automatically to be taught and it becomes compulsory subject. Teaching English in senior high school level has many obstacles so teaching English not maximum yet. It can be caused by some factors such as: big classes, limited facilities and relevant books, unclear technique or procedure of curriculum implementation and low quality of teaching learning process. Most of the senior high school has students more than forty students in each class, facilities are not sufficient, lack of relevant books, the teaching strategy is not effective yet.

One of the four language skills of English that is taught in SMA is reading skill. In general this skill has become dominant in the real teaching and learning activities because the teaching learning materials are in the form of books containing written text. In other words, the classroom activities are mainly related to reading text or passages. Understanding a written text means extracting the required information from it as efficiency as possible (Grellet, 1195). More comprehension is necessary when we read a text. By comprehending the text students can get the details and utilize the information and ideas of reading text. Shepherd (1979) in Nengah Sumarni (2011) defines reading comprehension as the ability of students to comprehend the information presented by the author. Reading comprehension should not be separated from other skills. It is therefore important to link the different skills through the reading. Reading is first of all a language ability. The raw material of reading sounds, words, sentences and communicative intentions are much the same as that language in general .

There are some obstacles in English teaching and learning are mostly caused by the contrary between the essential of studying a foreign language not too many students in the class, teachers must be professional, meeting frequency must be high and teaching strategy must be suitable. Sadtono ( 1991 :61-62 )

The students may be categorized into high reading interest and low reading interest and students with high reading interest will improve their achievement better than low reading interest. There 
were four objectives of this research related of the statements of the problems, there are (1) Is there any significant difference In reading comprehension between those who are taught by cooperative learning model and students who are taught by conventional learning model (2) Is there any interaction effect between cooperative learning model and the students' reading interest in effecting students reading comprehension? (3) Is there any difference in reading comprehension between students with high reading interest students who are treated with cooperative learning model and those treated with conventional learning model? (4) Is there any difference in reading comprehension between students who have low reading interest who are taught by using cooperative learning model and those who are taught by using conventional learning model ?

\section{THEORETICAL FOUNDATIONS}

1. Reading Comprehension Theories

Ashcraft (1989) states Reading comprehension is the ability to gain meaning from text. There are two categories of comprehension: Literal comprehension and inferential comprehension. Literal comprehension is the recognition and recall of explicitly stated information. Inferential comprehension. Readers use a variety of reading strategies to assist with decoding (to translate symbols into sounds or visual representtations of speech) and comprehension. Readers may use morpheme, semantics, syntax and context clues to identify the meaning of unknown words. Readers integrate the words they have read into their existing framework of knowledge or schema (schemata theory).

Richards et al. (1985). states that the process by which a person understands the meaning of a written language is called comprehension. As defined by Partnership for Reading (2005), Reading comprehension is understanding a text that is read, or the process of "constructing meaning" from a text. Comprehension is a "construction process" because it involves all of the elements of the reading process working together as a text is read to create a representation of the text in the reader's mind.

2. Cooperative Learning Model

Cooperative learning is both an instructional technique and a teaching philosophy that encourages students to work together to maximize learning (Cinelly, 1994 : 64 (3), 99 - 102). Killen (1996:78) states that cooperative learning model is a type of group work in which two or more students interact with the common goal of mastering specific academic material. Harmer (2007:124) states that group work has the some 
advantages, one of which is to promote learner autonomy by allowing learners to make their own decision in the group without being told what to do by the teacher.

\section{Conventional Learning}

Conventional learning is a strategy in which the process of learning is still considered as teacher centered. The teacher always dominates all the time and the activities step by step. Since the teacher is very dominant in learning process, the teacher must be able to be a good model for the students. Conventional learning orients on principles of psychological behavior and social study theory, especially about modeling. People study based on the model (Bandura,1963: 113), that imitate behavior and experience (success and failure) of other people. Most of the teacher's actions are to help students gain procedural knowledge, how to do something, and how to have experiment.

\section{Reading Interest}

Reading Interest is a sense of concern with and curiosity about reading and founding information that can hold people attention, encourage effort, and support learning through reading of written text Krashen, S.D. (2004). The powerful facilitative effect of interest on academic performance in general has been well established. For the purpose of this entry, the current conceptualization of interest is overviewed, followed by a review of interest research on reading. Interest is defined as a condition that occurs when one looks at the characteristic or temporary situation associated with the desires or needs themselves. What is seen is certainly going to arouse one's interest to sees how far it has links with it's own interest. This suggests that the interest is the tendency of one's soul to an object (usually accompanied by feelings of pleasure), because it felt there was interest in such objects. (sardiman, AM, 2001:74)

\section{RESEARCH METHODS}

This research was done at SMA Negeri 1 selong. The population was all students of grade eleven. The total number of population was 8 classes, which all together consisted of 256

Because of the experimental research, it needs four classes in the same characteristic. So the technique of sampling that used random sampling technique by using lottery. Random sampling is a selection of sample that is not done subjectively. Sample is not chosen by as a simple. The four classes then were drawn lots to determine experimental group and control group. Based on the lottery, classes XI IPA-1, XI IPA-2 were experimental group and classes XI IPA-3 and class XI IPA-3 and XI IPA- 4 were chosen as control group. 
The eleventh graders (XI IPA-1 and XI IPA-2) were as experimental class which consists of 64 students and the other class as a control class which also consisted of 64 students those were XI IPA-3 and XI IPA-4 From the result of reading interest questionnaire, $33 \%$ of low reading interest and $33 \%$ of high reading interest group were taken from both classes of experimental class and control class. So, there were 42 students for experimental class and 42 students for control class.

The design was used in this research was $2 \times 2$ factorial design. In this design, the population was divided into two groups; an experimental group and a control group. There were two independent variable, one variable that was categorized as cooperative learning model (A1) for experimental group and conventional learning model (A2) for the control group and one control variable that was categorized as high reading interest (B1) and low reading interest (B2) in both experimental group and control group.

The instrument to collect data were reading comprehension test, and reading interest scale in studying English. Both of instruments had been tried out to ensure their validity and reliability. Data for this research were collected by using test and non test . Data which were collected by using test is reading comprehension data. To collect this data the students were answer the questions of reading test. Their answers were then analyzed and scored by two rater's score, the inter-rater reliability analysis was conducted for each test.

The second data was the data which were collected by using non-test instrument. This data were collected by using the scale of reading interest in studying English. The students were given the scale to be responded. Score for each item was then added up to obtain Reading Interest in studying English score of each students.

The data were analyzed by using descriptive statistic and inferential statistic which was done by using two- way ANAVA and continued by post hoc analysis namely Tucky test . Before the researcher further analyzing data, the data were tested in order to find out whether it had normal distribution and homogeneity of variance or not. From the test namely the Kolmogrov-Smirnov statistic to investigate the normality, it was found that the data was normally distributed. Also, Levence's test of equality of error variance found that the homogeneity of variance data was homogeneous.

\section{FINDING AND DICUSSION}

This research tried to answer four research problems. The following will explain each of the findings that answer each research problem, furthermore, the 
discussion of the findings is also provided.

The research problem was questioning whether, The data that is described in this research is the English Reading Comprehension as the result of cooperative learning model and conventional learning model. The design that is used in this research was factorial design $2 \times 2$ by using Two Way Analysis of Variant as a means of data analysis. The data in this research is categorized: (1) The result of students' English reading comprehension of those who were taught by using cooperative learning model, (2) The result of students' English reading comprehension of those who were taught by using conventional learning model, (3) The result of students' English reading comprehension of those who had high reading interest and being taught by using cooperative learning model, (4) The result of students' English reading comprehension of those who had low reading interest and being taught by using cooperative learning model, (5) The result of students' English reading comprehension of those who had high reading interest and being taught by using conventional learning model, and (6) The result of students' English reading comprehension of those who had low reading interest and being taught by using conventional learning model.
1. Data of the Students who were taught by cooperative learning model.

From 44 students who were taught by cooperative learning model, maximum score that was achieved was 41 and minimum score was 31, mean 35.45, median 35.25, modus : 34.00, and deviation standard : 2.467 .

2. Data of the Students who were taught by Conventional Learning model

From 44 students who were taught by conventional learning model, maximum score that was achieved was 38 and minimum score was 20, mean: 30.36, median: 31.0000, modus : 29.00, and deviation standard : 4.956, variance: 24.562, range: 18.00 .

3. Data of the Students Who had high reading interest

From 44 students who had high learning motivation, maximum score that was achieved was 41 and minimum score was 20 , mean 34.16, median 35.25, modus : 37.00 , and deviation standard : 4.564, variance: 20.835 , range: 21.00 .

4. Data of the Students who had low reading interest

From 44 students who had low reading interest, maximum score that was achieved was 37 and minimum score was 20, mean : 31.166, median 33.08, modus : 34.00, and standard deviation : 4.456, variance: 19.858 , range: 17.00 . 
5. Data of the High reading interest Students who were taught by cooperative learning model.

From 22 students who were taught by cooperative learning model and had high reading interest, maximum score that was achieved was 41.00 and minimum score was 34.00, mean: 37.09, median : 36.89, modus : 37.00, and deviation standard : 1.998, variance: 3.991, range: 7.00 .

6. Data of the Low reading interest Students who were taught by cooperative learning model

From 22 students who were taught by cooperative learning model and had low reading interest, maximum score that was achieved was 37.00 and minimum score was 31.00 mean :33.82, median :33.88, modus : 34.00 , and deviation standard : 1.680 , variance $: 2.823$, range $: 6.00$.

7. Data of the High reading interest Students who were taught by conventional learning model.

From 22 students who were taught by cooperative learning model and had high reading interest, maximum score that was achieved was 38.00 and minimum score was 20.00, mean : 31.23, median : 31.75, modus : 32.00, and deviation standard : 4.545 , variance : 20.660 , range : 18.00 .

8. Data of the Low reading interest Students who were taught by conventional learning model.

From 22 students who were taught by conventional learning model and had low reading interest, maximum score that was achieved was 37.00 and minimum score was 20.00, mean : 29.50, median : 29.50, modus: 29.00, and deviation standard : 5.298 variance : 28.071 , range : 17.00 .

From the statistical analysis to find significant difference between cooperative learning model and conventional learning model in improving reading comprehension, it was found that $\mathrm{F}_{\mathrm{A}}(35,45)$ was higher than $\mathrm{F}_{\mathrm{CV}}(30,36)$. Therefore, Ho was rejected. This mean, regardless the learning reading interest factors, there was a significant difference between the reading comprehension of the students who were taught by cooperative learning model and those who were taught by conventional learning model.

Regarding moderator variable, the reading comprehension of the students who had high reading interest, who were taught by cooperative learning model was higher than those who were taught by conventional learning model. This finding proved that cooperative learning model could increase English reading comprehension of the students of SMAN 1 Selong. Cooperative learning model was very effective, because by using this model, students could learn and teach one 
another among the students.

The basic concepts of cooperative learning enable the students to develop according to their ability and their talent. Some steps in cooperative learning can give good chance for the students to increase their skills and ability in reading comprehension.

Statistical analysis showed that conventional learning could not so affect positively toward the reading comprehension of the eleventh grade students of SMA Negeri 1 Selong. Conventional learning did not give chance for the students to develop autonomously. This model places the students as an object of learning or as a receiver of information passively. In learning activities, most of the students study individually, students study the lesson by receiving, noting, and memorizing the material that is seldom related to their real life, and also the material that has been taught tends to be theoretical and abstract. Besides that, students do not have much opportunities to improve their achievement because their comprehension is directly punished by quantitative score for every student's work without giving opportunities to the students for improving.

In this research, discussion was also done to investigate whether there are other factors that influence the reading comprehension of the eleventh grade students of SMA Negeri 1 Selong or not. Based on the purpose of this research, discussion was continued by analyzing the role of reading interest in increasing the students' reading comprehension.

The result of hypothesis testing that analyzed whether there was significant different achievement on students who had high reading interest between those who were taught by cooperative learning model and those who were taught by conventional learning model or not. It could be seen at the mean of reading comprehension for the experimental group was 37,09 and for the control group was 31,23 . It means that the reading comprehension of the high reading interest students who were taught by cooperative learning model was higher than the reading comprehension of the high reading interest who were taught by conventional learning model. And also Tukey Testing showed that $\mathrm{Q}_{1}=4,119$ and $\mathrm{Q}_{\text {table }}=2,83$, This means that $\mathrm{Q}_{1} \geq \mathrm{Q}_{\text {table. }}$ There was significant difference of achievement on students who had high reading interest between those who were taught by cooperative leaning model and those who were taught by conventional learning model. This statistical analysis proved that the reading comprehension of the students was not only affected by the learning model but also it was affected by the reading interest.

Such as this research, that was 
conducted by some previous researchers reported that there was a significant effect between students' reading interest and students' reading comprehension.

Based on the above findings, it can be said that cooperative learning model is a suitable model for the students who had high reading and students who had low reading interest. On the other hand, for the students who had low reading interest if they were taught by cooperative learning model was less affected to increase the students in reading comprehension, because they regarded that cooperative learning is a complicating model, so they felt that they we forced to learn again and again to understand well, while conventional learning is usual for them, they felt that conventional learning is not complicated.

For the students who had low reading interest preferred usual situation which makes them pleasant and comfortable. They are lack of readiness to achieve critic or suggestion because they regard that feedback that is given for them show their weakness, and at last, they decrease their reading interest.

Previous researchers have much explained that cooperative learning model has more excess than conventional learning model. It cannot be avoided that cooperative learning model has positive impact toward the students' reading comprehension. Based on this study, the significant impact occurred on students who had high reading interest. It showed that reading interest is a significant factor for increasing students' achievement. Without reading interest, the effect of learning model will not be able to disseminate the students' achievement.

It is an interesting phenomena in relating high reading interest with cooperative learning model in learning process. It can be said that cooperative learning model has positive effect toward the high reading interest students, but cooperative learning model has less effected toward the low reading interest students. It means that improvement of the achievement occurred if the cooperative learning model was used for the students who had high reading interest.

It does not mean that cooperative learning model is not only for high reading interest students. Reading interest is really important, it makes the students passion, strong desire and pleasant, because of that students who have high reading interest have more energy to study. Students who have high reading interest tend to be successful and a little bit of mistakes in learning.

It can be concluded that cooperative learning model can increase reading comprehension if it is used for the students who have high reading interest. For the 
students who have low reading interest, cooperative learning model can also increase reading comprehension, provided they are made sure to be active to try the new model. This effort can be done by building their self-confidence that cooperative learning model is not too complicated, on the contrary, it can help the students to increase their reading comprehension. If they are used to learning by cooperative learning model, they were able to increase their reading interest while they were able to increase their reading comprehension.

Then, whether there is interaction between reading interest and reading comprehension, the hypothesis testing showed that $F$ value 0.946 and $p=0.334$. it means that there is an interaction between cooperative learning model and level of reading interest that affect the students' achievement. This testing proved that there was an interaction between the model that was used and reading interest toward the students' English Reading Comprehension.

Sardiman (2001 75) says that in learning activities, reading interest can be said a motivator of power that creates and guarantees the continuity of learning activities, with the result that, the desired aim of the learners can be achieved. It is said that the high reading interest students have more energy for learning activities. But the low reading interest students, they have no strong desire to learn, except they are forced to learn. There is also a student who has high intelligence, but he/she fails his/her study, because of he/she has no reading interest. Reading comprehension can be optimal if there is high reading interest. A student who learns English, besides having basic competence that was being taught, a student is always demanded to follow the newest development of the material that is being taught. As a consequence, a student must have high spirit and high reading interest to achieve the basic competencies involved in curriculum year 2006.

The discussions indicate that there is interaction between reading comprehension, cooperative learning model, and reading interest. English is one of the subjects that posesses very clear aim i.e. to be able to use English as a means of communication in oral or written language, One of the advantages of cooperative learning model is widely giving chance for the students to practice reading comprehension which include organization, Content knowledge, grammar, spelling, and neatness. Using cooperative learning model, students can ask and answer among their friends under teacher's guidance.

The student who has high reading interest is found of challenges and always looks for the newest information. So that, he/she always hopes feedbacks that he/she 
uses to increase his/her achievement.

All the above discussions about English reading comprehension, cooperative learning model, conventional learning model, and reading interest have explained that there were interaction among them.

\section{CONCLUSION, IMPLICATION AND SUGGESTION}

Based on the result of the data analysis, some conclusion can be stated as follows: (1) There was a significant in English reading comprehension of the students who were taught by using cooperative learning model and those who were taught by using conventional learning model. (2) There was an interaction effect between cooperative learning model and conventional learning model at the students reading interest (3) There was a significant difference in the reading comprehension between high reading interest students who taught by using cooperative learning model and those who were taught by using conventional learning model. (4) There was no significant difference in the reading comprehension between low reading interest students who taught by using cooperative learning model and those who were taught by using conventional learning model. (5) The implementation of cooperative learning model were responded more positively by students who have high reading interest than student who have low reading interest.

\section{IMPLICATIONS}

It has been explained previously that the result of the research indicated that students, reading comprehension were affected by implementation of cooperative learning model. The reading comprehension of the students who were taught by using cooperative learning model was better than those who were taught by using conventional learning model.

Having known that the implementtation of cooperative learning model affected differently to students reading comprehension, specifically for the students who have high reading interest, it is then strongly implied that the teachers should reconsider the implementation of conventional learning model. The observation in the classroom showed that the students become more confident and easy to understand the vocabulary of the reading material because the students who have high reading interest help the students who have low reading interest. It showed that when the students are low reading interest matched with the cooperative learning model applied by the teacher, student reading comprehension in learning English especially in reading comprehension would increase.

\section{SUGGESTIONS}

Based on the research finding 
presented previously, it is strongly recommended previously that:

First, Teachers should implement the cooperative learning model in teaching reading comprehension, particularly, for the students who have high reading interest. Moreover, cooperative learning model can also be applied for the students who have low reading interest as way to improve those students reading interest in reading comprehension. But the teacher must control the class well to avoid the dominancy of students who have high reading interest in the classroom.

Second, since achievement reading comprehension has significant role in contributing students' reading comprehension, the English teachers are expected to know the level of their students reading comprehension since it will influence the choice in implementing teaching techniques in the classroom.

Third, Students should be aware about their own the reading comprehension when they recognize their level of the reading comprehension, they must maximize the strength and minimize the weaknesses to obtain a good achievement in language learning specially in reading comprehension.

Fourth, for other researcher, it is recommended to conduct a research on some variables in which the result of study can affect students' reading comprehension achievement. Since this research used cooperative learning model and students reading interest as moderator variable, it is suggested to think about other teaching models and variables which may affect students reading comprehension skill. The research can be conducted on different settings, subjects, and material as well to obtain a more comprehensive research.

And the last, it is also recommended for the teacher to see the students the reading interest in learning specifically in selecting teaching model and designing lesson activities. So, the goal of learning English specially in reading comprehension can be achieved.

\section{REFERENCES}

Ashcraft Mark H (1989, Human Memory and Cognition, Paperback)

Badan Standar Nasional Pendidikan, 2006. Jakarta: Depdiknas.

Bandura, Albert and Walters, Richard $\mathrm{H}$. 1963. Social Learning and personality Development. New York: Holt, Rinchart and Winston.

Cinelli,B.1994. Applying Cooperative Learning in health education practice.

Harmer, Jeremy 2007 Practice of English Language Teaching. New York: Logman

Haliday,1973. Exploration in the functions of London : Edward Arnold

Killen, Roy 1998. Effective Teaching Strategies, Lesson from Research 
and Practice, Second Edition, Australia: Social Science Press.

Krashen, S.D. (2004). The power of reading: insights from the research. $2 \mathrm{~d}$ ed. Westport CT: Libraries Unlimited \& Portsmouth NH: Heinemann.

Richard, J. C (ed) 2006. Cooperative Learning and second Language Teaching Cambridge: Cambridge Language Education.

Sardiman, A. M. 2001. Interaksi dan Motivasi Belajar Mengajar, Jakarta: Rja Grafindo Persada.

Sadtono, Eugenius 1991, language Acquisition and the Second Foreign Language Classroom, Singapore: searne Language centre 